In the Beginning was the Big Toe:

Bataille, Base Materialism, Bipedalism

\title{
Matthew Beaumont
}

In the beginning was the big toe. Or, to formulate it in terms of a base-materialist philosophy, being begins with the big toe.

In an essay on the mouth from 1930, the renegade Surrealist philosopher Georges Bataille stated that "man does not have a simple architecture like beasts, and it is not even possible to say where he begins". ${ }^{i}$ As Roland Barthes understood, it is a statement of some philosophical importance. In "Outcomes of the Text", Barthes noted that "Bataille raises the question of the beginning where it had never been raised: 'Where does the human body begin?"'ii Bataille's claim is that the mouth is the beginning, or "prow", of animals. Implicitly, then, the anus, or perhaps the tail, is the end of animals. Bataille confronted this end, in the form of an ape's protuberant anus, its "anal projection", on a visit to London Zoo in July 1927 - an encounter that, because it seemed to him to violate the discreet seclusion of the human anus, proved at the same time horrific and epiphanic. ${ }^{\text {ii }}$

Bataille insists that, in contrast to an ape's body, a man or woman's body does not have a beginning or an ending. Reading Bataille against Bataille, in this article I want to argue instead that, as a species, the human being begins with the big toe. In 
1929, a year before he published his essay on the mouth, Bataille wrote an essay on the big toe in which he contended that, although the big toe is routinely regarded as base, it is paradoxically the most noble bit of the human body. The big toe is risible, if not contemptible, but it is secretly responsible for giving "a firm foundation to the erection of which man is so proud". "The big toe is the most human part of the human body,' he explains, 'in the sense that no other element of this body is so differentiated from the corresponding element of the anthropoid ape". ${ }^{\text {iv }}$ In spite of this, though, or because of it, it is routinely bound, hidden and treated as something shameful. The big toe is thus both the most significant part of the human anatomy and the part most neglected or denigrated in the cultural imagination.

Le gros orteil, as the big toe is called in France, is in a dual sense gross: it is generally thought to be at once excessively obtrusive and repulsive. In terms of the politics of the body, as Shakespeare speculated, this makes the big toe analogous to the most strident representatives of the oppressed sections of society. In Act I, Scene I of Coriolanus, set in the Roman street, the patrician Menenius Agrippa characterizes the situation confronting the state in terms of the metaphor of the body politic. In his allegorical speech, he identifies the big toe as the leading figure in an insurrection of mutinous body parts against the belly, which stands in for the Senate, the locus of power. "What do you think," Menenius asks his interlocutor, the rebellious First Citizen, "You, the great toe of this assembly?" "I the great toe!" the Citizen responds indignantly, "why the great toe?"

For that, being one o' the lowest, basest, poorest, Of this most wise rebellion, thou go'st foremost:

Thou rascal, that art worst in blood to run, 
Lead'st first to win some vantage. $(1.1 .154-8)^{\mathrm{v}}$

The big toe, according to Menenius's metaphor, is the last part of the body to receive the nutrition circulated through the bloodstream by the belly, which stores, processes and distributes energy. Hence it is the most disgruntled, cantankerous part of the body, the first to agitate for revolution. The lowest, most extreme part of the body, the big toe, will act as the vanguard of the insurrectionary body. The basest will go foremost. It is as if Bataille was glossing this scene from Coriolanus when he wrote that "the hideously cadaverous and at the same time loud and defiant appearance of the big toe [...] gives shrill expression to the disorder of the human body, that product of the violent discord of its organs". ${ }^{\text {i }}$ As a consequence of this rebellion of the body parts, the gros will become grand.

Bataille announces in "The Solar Anus" that "Communist workers appear to the bourgeois to be as ugly and dirty as hairy sexual organs, or lower parts". Among these lower parts he is surely thinking of the big toe. He adds in a spirit of insurgency that "sooner or later there will be a scandalous eruption in the course of which the asexual noble heads of the bourgeois will be chopped off'. ${ }^{\text {vii }}$ If the etymological meaning of the word "scandalous" is insecure, wobbly, or limping, as Barthes insists in his commentary on Bataille, then the big toe must play a leading role in displacing the bourgeois regime of the human body in which the head is dominant. As in the citizens' rebellion in Coriolanus, it must give shrill expression to the disorder, the violent discord, of the various organs and parts that comprise the human body. Bataille, it might be said, calls for the dictatorship of the toeleprariat.

The big toe describes what Bataille, recalling a dream, characterized as a "kind of ambivalence between the most horrible and the most magnificent". viii And it 
is on this dialectic of the magnificent and the horrible, the heroic and the pedestrian, the highest and the lowest, that my article concentrates. I should admit from the outset, though, that for the most part it overlooks the idea of the big toe as a fetish. Freud refers to the origins of this semi-comic role in his comments on infantile sexuality in 1910 , where he notes that, for the child, the lips, the tongue, the thumb "and even the big toe" may be taken as objects for sucking, in spite of the fact that they offer no nourishment (as the mother's breast once did). ${ }^{\text {ix }}$

Barthes, silently leaning on Freud, summarized this dimension of the big toe in a comment on its characteristic dynamics of desire: "the toe is seductiverepulsive." "The "seductive-repulsive" is very much the shifting, unstable terrain on which Bataille's thought operates: "Extreme seductiveness is probably at the boundary of horror," he observes in his essay on another bodily organ, the eye. ${ }^{\mathrm{xi}}$ But Barthes, who seems to have been entranced but never finally satisfied by the interest he felt in Bataille, seduced but oddly repulsed, domesticates his compatriot's untameable philosophizing when he concludes his account of the fetishistic character of the big toe with this aphoristic sentence: "fascinating as a contradiction: that of the tumescent and miniaturized phallus."xii

Bataille himself, as Rosalind Krauss correctly emphasizes, "does not work along the logic of the fetish"; and his essay on the big toe "explicitly dismisses the play of substitutions. Of sublimations. Of foot = phallus" xiii In what follows, then, I largely neglect this aspect of the big toe. I am concerned less with the tumescent and miniaturized phallus than with the big toe per se, especially in so far as it is largely responsible for the fact that human beings are bipedal. This article is about beginning with the big toe in both an anthropological (or palaeo-anatomical) sense and an 
iconographical one. I will examine these associations in turn before going back Bataille's philosophical reflections on the big toe.

II

In evolutionary terms, human beings can be said to begin with the big toe. That is, our identity as a species hinges, or pivots, on the development of the big toe - because it is cause or consequence, or both cause and consequence, of the fact that, to put it in pictorial terms, instead of climbing trees we walk across plains. It is responsible for the fact that we are bipedal. In short, it is what makes us human. In The Descent of Man (1871), Charles Darwin quoted his old antagonist Richard Owen, an opponent of the theory of evolution by natural selection, to this effect: "The great toe, as Prof. Owen remarks, 'which forms the fulcrum when standing or walking, is perhaps the most characteristic peculiarity of the human structure'."xiv

The basic structure of our body is shared both with our evolutionary ancestors and our immediate relations, that is, chimpanzees and other apes. Obviously there are quantitative differences between a human and a chimpanzee brain, and the left and right halves of the brain have developed differentially; but anatomically they are directly equivalent. To put it in terms of aesthetics, formally they are the same, even if they have different contents. And this is true of the eyes, the nose, the breasts, the penis and every other body part. The exception is the big toe. For the big toe, in contrast to the innermost toe of our ancestors and our genetic cousins, is not opposable in humans, as the thumb is. We do not have a prehensile big toe. On the contrary, we have one that has evolved to enable us to walk rather than climb; and 
indeed, crucially, to develop tools. "One cannot overemphasize the role of bipedalism in hominid development," the archaeologist Mary Leakey, who discovered the Laetoli Footprints, argued; "this unique ability freed the hands for myriad possibilities carrying, tool-making, intricate manipulation." ${ }^{\mathrm{xv}}$

The toe of the human foot is adducted: it is drawn inwards. The toe of the chimpanzee is abducted: it is drawn outwards. Or, to put it another way, if the chimpanzee's big toe is divergent, like our thumb, then the toes of the human foot are instead convergent (the big toe has aligned with the other toes, or vice-versa). In addition, a human being's middle footbone is far more compact than that of the chimpanzee, and it is consequently less mobile, more stable; and these relatively dense, rigid, solid bones can be used to lever the body in walking. So even though it now seems that the earliest anatomical changes relating to bipedalism didn't in fact occur in savannahs, as a result of deforestation, there is no doubt that these features of the emergent human foot would have helped humans to survive in the plains, perhaps giving them an evolutionary advantage over other primates, who were unable for instance to track migratory herds across the savannah. And research in fact suggests that bipedalism preceded distinctive and decisive brain development in humans. It is because the big toe became adducted that the brain expanded and humanity emerged.

The big toe, then, is the most distinctively human part of our anatomy and the one that guarantees our unique status in evolutionary terms. As the authors of a clinical textbook on the human foot summarize the point, anatomically modern humans, which emerged about 150,000 years ago, "are the only living primate, indeed they are the only living mammal, that is an obligatory striding biped."xvi Obligatory bipeds are animals that rely solely on their hindlimbs for support and propulsion when walking on the ground. All other primates are characterized by optional bipedalism. 
Other primates have a "locomotor repertoire", as it is called, that is mixed - in other words, they use a range of means of moving about that includes, for example, balancing, hanging, jumping and quadrupedalism, as well as occasional bipedalism. For this reason they have a divergent hallux. Humans are by contrast committed to a single locomotor mode - "obligate bipedalism". It is this that explains the other architectural features that, in spite of their anatomical similarity to the equivalent parts of primates, are characteristic of our bodies in particular: the long, straight legs; the protuberant buttocks (which, in contrast to those of the ape glimpsed by Bataille, conceal the anus); "the flat stomach, the flexible waist, the straight spine, the low shoulders, the erect head atop a long neck." ’vii

The causes of the evolutionary shift to a flat, non-prehensile, in short, modern human foot are still debated, and the answers that scientists tend to volunteer only raise further questions. It might be that the bipedal feet developed in humans as an adaptation enabling them to carry food or infants. It might be that they developed in order to minimize exposure to the tropical sun and so preserve energy in a hot habitat. Conversely, it is possible that, for some reason, humans' forelimbs were used for purposes other than locomotion for prolonged periods, and that bipedalism came to be the most efficient means of locomotion as a result - for example, it has been claimed by some scientists that humans first learned to walk in trees, on an arboreal rather than terrestrial surface, using their arms to suspend and support themselves from higher branches. It is also possible that it was the development of an upright posture perhaps in order to facilitate displays of aggression or virility - that created the evolutionary conditions for bipedal locomotion. ${ }^{\text {xviii }}$

The consequences, or coterminous developments, of bipedal locomotion, to which the quotation from Leakey alluded above, are almost as debatable as its causes. 
Recently, for example, one group of scientists has argued for the co-evolution of human hands and feet, arguing that "evolutionary changes in the toes associated with bipedalism caused matching evolutionary changes in hand anatomy that may actually have facilitated the emergence and development of stone tool technology." These biologists propose that when Australopithecus afarensis, a partly arboreal, so-called facultative biped, evolved into Homo, an obligate terrestrial biped which probably did a good deal of long-distance trekking, a change that occurred about two million years ago, the directional selection on the lateral toes for locomotion "may have caused parallel changes in the fingers that provided further performance benefits for manipulation". xix According to this thesis, the morphological development of the toes, which became adapted for long-distance walking or running, increased the length and robusticity of the australopiths' thumbs, and so made it possible for humans to become the sophisticated, precise tool-makers that gave them such an evolutionary advantage.

In a rather different register, of course, and getting on for a century ago, Freud speculated in Civilization and its Discontents that what he called "man's decision to adopt an upright gait" led directly to "the decline of the olfactory stimuli", and hence to the association of bodily dirt and smells with shame. "The beginning of the fateful process of civilization, then," he concludes, "would have been marked by man's adopting an erect posture" - that is, by becoming an obligate biped. ${ }^{\mathrm{xx}}$ The emergence of the big toe is according to this perspective responsible for the beginnings of civilization, and for the history of repression that defines it. Hence the big toe is in effect the precondition of sexual fetishism, as well as one of its privileged objects. This is an additional sense in which we could be said to begin with the big toe. 
The peculiar type of primate locomotion known as obligate bipedalism, it can be concluded, probably first started to evolve between about five million and eight million years ago (although precise dating is extremely difficult, largely because fossils of the foot are extremely rare, since predators and scavengers have a predilection for the red marrow in the tarsal bones, and consequently tend to eat the feet of their prey). We can however be fairly confident that early hominid species such as Australopithecus had predominantly grasping feet, and relatively prehensile big toes, until roughly 3.2 million years ago. ${ }^{\text {xxi }}$ The recent discovery of a fossilized foot in the Afar region of north-eastern Ethiopia, which has been dated to 3.4 million years ago, seems to confirm that pre-human ancestors were adapted at least partially to an arboreal existence, because the big toe juts out to the side like that of a gorilla or chimpanzee. This hominid species was probably a contemporary of Australopithecus, which had lost similar bone features in favour of other adaptations that committed it to walking on two feet, as the remains of "Lucy", several hundred pieces of whose bones were found in 1974 in the same region of eastern Africa, indicates.

Obligate bipedalism and the convergent big toe on which it depends developed rather belatedly, in evolutionary terms; and the human foot, with its everted rather than inverted posture, and its characteristic distribution of the metatarsals in a transverse arch configuration, is thus a comparatively recent anatomical structure. This might help to explain why our feet are so susceptible to signs of maladaptation and malfunction. "Humanity has tortuously walked across the ages on two feet with a skeleton designed originally for four-legged travel," as Joseph A. Amato has pointed out; "flat feet, swollen feet, distorted toes, blisters, bunions, hammer toes, trick knees, herniated discs, and bad backs, not to mention hernias, hemorrhoids and other maladies associated with our bipedal locomotion, remain the price of standing 
proudly erect."xxii Or, as Bataille puts it, in diction that characteristically combines the sacred and profane, the human foot, though it gives "a firm foundation to the erection of which man is so proud", "is stupidly consecrated to corns, calluses, and bunions, and $[\ldots]$ to the most loathsome filthiness". xxiii

The malfunctioning of the foot - in evolutionary terms, its belatedness - is perhaps one of the reasons for the ignominious status of the big toe in the history of representations of the human body. For its iconographical insignificance. The big toe has been developed too hurriedly. It is a botched job, a strangely Frankensteinian touch. But, if it is belated, it is also an advanced piece of technology, highly effective both at providing propulsive force and withstanding weight. It is a prosthesis that makes it possible to walk and to go on walking. This contradiction is central to Bataille's interest in the big toe. The grossest, the ugliest, arguably the most alienlooking and least human-seeming, part of the anatomy, is actually what makes us human. Conversely, the big toe is the part of our body that, in spite of its crucial role in enabling us to stand upright, and so transcend our brute past, most closely resembles a vestigial trace of that brute past, of some primitive, primeval, muddy origin. The big toe, to take a formulation from Nick Land, "protracts the trajectory of animality;" but it also projects beyond it. ${ }^{\text {xxiv }}$

III

In order to defend this digit against its denigration in iconographical terms, it is imperative to imagine reorganizing the entire history of art in relation not to the head, which has long been its privileged domain, but the big toe. 
This is in effect what the Italian novelist Carlo Emilio Gadda proposed. At one point in his most celebrated novel, the late modernist masterpiece That Awful Mess on the Via Merulana (1957), the carabiniere private Cocullo finds himself standing in front of a fresco of two saints attired in short cloaks, which reveal "four unsuspected feet" (271). The two right feet are "generously tentacled in toes", toes which are "stretched forward in their stride", and which "puncture the foreground" of the composition. Gadda then rhapsodizes as follows:

With particular expressive vigor, in a remarkable adaptation to the mastery of the centuries, the big toes were depicted. In each of the two extended digits, the cross strap of otherwise unperceived footwear segregated and singled out the knuckled-toe in that august pre-eminence which is his, which belongs to the big toe, and to that toe alone, separating it out from the flock of the toes of the lower rank, less suitable for the day of glory, but still, in the osteologues' atlases and in the masterpieces of Italian paintings, toes. The two haughty digits, enhanced by genius, were projected, lurked forward: they traveled on their own: they almost, paired off as they were, stuck in your eye; indeed, into both your eyes: they were sublimated to the central pathetic motif of the fresco, or alfresco, seeing as how it was plenty fresh. A bolt from heaven, a light of excruciated hours blanched them; however, when you came right down to it, the light seemed to rise from underground, since it struck them from below. ${ }^{\mathrm{xxv}}$

The big toes project, lurk forward - they stick in your eye. They belong, that is, to a different order of perspective to that of the rest of the composition. In their obtrusion 
from the picture plane, they acquire an almost anamorphic quality, like the smeared skull that emblematizes Death in Holbein's celebrated portrait of the Ambassadors. They travel on their own, in Gadda's phrase, like entities from a different order of being. Gadda has excavated the distinct ontological space of the big toe - its ontoelogy.

The big toe in the painting described by Gadda, brilliantly refulgent, synthesizes Apollonian and Dionysian energies, the high and the low, the magnificent and the horrible. The camp extravagance of his ekphrastic digression seems unsurpassable. But Gadda's hymn to the big toe does not end at this point. He has only just begun. For he proceeds to make an even more ostentatiously counterintuitive claim: "The glorious history of our painting, in a part of its glory pays tribute to the big toe. Light and toes are prime ingredients, ineffable, in every painting that aspires to live, that wants to have its say, to narrate, persuade, educate: to subjugate our senses, win hearts from the Malign One: insist for eight hundred years on the favorite images." This is an elaborate pun on la luce (meaning "light") and l'alluce (meaning "big toe"). A couple of pages later, poring over "the two big toes, the Pietrine and the Pauline", portrayed in a shrine to the due santi, Gadda brings this pun to its cosmic climax: “The 'creator' couldn't bear another moment's delay, before creating," he declares, apparently alluding both to the painter and to God: "“Fiat lux!" And there were toes. Plip, plop" (274-5). It is as if creation itself is a ridiculous, Beckettian accident caused by a slip of the tongue. Let there be toes. I mean, light. Too late. In this absurdist theology, the universe has come into being not because light has split apart the darkness but because a gigantic big toe has irrupted into it. Gadda goes on to explore his thesis in relation to more canonical paintings. The first is Michelangelo's Doni tondo, a painting which, implicitly playing with its 
circular form, he rotates, symbolically speaking, so as to pivot it on its representation of the big toe. There, in the exquisitely delicate tension between "the inimitable big toe" of St. Joseph and "the little toe of the Bride", he perceives "the Toe-Idea": "a livid and almost surreal, or perhaps eschatological light, proposes the Toe-Idea, loftily incarnating - or in ossifying - it, in the foreground of the contingent" (273). The casual almost-contact between Joseph's big toe and Mary's little toe is nearly as significant as the far-from-casual, the causal almost-contact between God's index finger and Adam's in Michelangelo's painting of "The Creation of Adam" on the ceiling of the Sistine Chapel. Raymond Tallis, who has argued for the quintessentially human quality of the index finger, admits in a reference to this fresco that he "like[s] to think that the slightly awkward encounter between God and man through their index fingers depicted by Michelangelo [...] was influenced by an intuition of the central role of the index finger in making us so different". ${ }^{x x v i}$ I like to think that the slightly awkward, but infinitely tender, encounter between Joseph's big toe and Mary's little toe in the Doni tondo, as indicated or pointed to by Gadda, was influenced by an intuition of the central role of the big toe in making human beings so different. Certainly, it is the index of these saints' humanity.

The other painting that Gadda reinterprets in relation to the big toe is Raphael's "Lo Sposalizio della Vergine”, in the Brera, which depicts Mary and Joseph being married by a priest, in front of a temple, among assorted onlookers. Gadda's interest lies in Joseph's left foot, since it is there that, in order to symbolize his chastity, "the same metatarsus protuberates, the foot's thumb":

The divarication of the solitary, bony toe from the remaining herd of other toes is rendered prominent by the perspectively charming joints of the 
cleansed pavement, where there is no husk or skin, neither orange's nor chestnut's, nor any leaf or paper settled there, nor has man urinated, nor dog. And the master toe, though disjoined from the others, at its root is spurred and gnarled: and then it converges inwards, as if forced by gout or by the habitual constriction of a shoe momentarily removed, or I'd say domum relapsa as if too fetid for the hour of the wedding. (273-4)

On the beautifully clean surface of the pavement, the big toe so tenderly painted by Raphael displays both the holiness and the ordinariness, the spirituality and the physicality, of this saintly artisan: "more than a toe of more than a barefoot carpenter", as Gadda puts it (274). It has been liberated from the stinking shoe that encased it and consecrated to a divinity who one day shortly before his death will advertize his humility and his ordinary humanity by washing the feet of his disciples. Gnarled, spurred, and gouty, in short, horrible; it is also magnificent. If Thomas Lee's feet in Geerhaerts' portrait are symbolic, then Joseph's are instead phatic. This is a gesture that transmits not social meanings but merely a minimal sense of his being.

In Gadda's baroque elaborations, it is possible to identify a profound grasp of the unity I have pointed to in this talk between the sublime and bathetic aspects of the big toe. Elevating the big toe, in the form of the Toe-Idea, he glorifies the contingent, the basely material. Fiat lux. Plip plop. In the article on the big toe Bataille describes this sort of slippage in terms of the dialectic of ordure and the ideal. ${ }^{\mathrm{xxvii}}$ This ToeIdea, with its violent collision of the spiritual and the basely material, is invoked again in a religious context, also to scurrilously satirical effect, in Thomas Pynchon's The Crying of Lot 49 (1965). There, Oedipa Maas attends a performance of The Courier's Tragedy, a revenge tragedy by one Richard Wharfinger. In the second act of this 
parodic Jacobean drama, which centres on the "protracted torture and eventual murder of a prince of the church" by the evil Duke Angelo, the cardinal in question is apparently "forced to bleed into a chalice and consecrate his own blood, not to God, but to Satan": "They also cut off his big toe, and he is made to hold it up like a Host and say, 'This is my body,' the keen-witted Angelo observing that it's the first time he's told anything like the truth in fifty years of systematic lying." "xxviii The amputated big toe is the central symbol of the satanic theology imagined by Pynchon. Its bleeding stump, consecrated to the Malign One, is the sacred emblem of a materialist anti-religion.

The big toe once again asserts the animality and the humanity of humanity. Here is a metaphysics of the foot in all its messy materiality.

IV

Gadda's revisionist account of Renaissance art, in which he seizes on the most insignificant feature of its iconography, iconicizing the non- or anti-iconic, is also a guide to his own innovations - at once literary and philosophical - as a writer. For, as Italo Calvino underlined, in addition to forging an extraordinarily original use of language, in which the erudite and the popular are freely, energetically intermingled, Gadda developed a form of narrative composition "in which minimal details take on giant proportions and end up by occupying the whole canvas and hiding or obscuring the overall design". ${ }^{x i x}$

This obsessive insistence on contingent matter is characteristic of Bataille's method too, and in conclusion I want to return to his essay on the big toe. "Le gros 
orteil" was first published in the sixth issue of Documents, the strange, cryptoanthropological journal that Bataille edited, and which he had set up as a materialist riposte to the idealist tendencies, as he regarded them, of Breton's brand of Surrealism. As Michel Surya says, the article was an "unrestrained parody of poetic idealism", and it was in this sense typical of Documents, which used its "rancid" ideas to leave "a doubtful taste in surrealism's mouth". ${ }^{x x}$

To illustrate "Le gros orteil", Bataille commissioned three photographs of big toes from Jacques-André Boiffard. Boiffard, who had taken the photographs that adorn Nadja, was a relatively obscure and insignificant actor in the Surrealist movement, but Breton nonetheless cited him in the first Manifesto of Surrealism as one of only two visual artists list of those who had "performed acts of Absolute Surrealism". The remarkable photographs he took for Bataille, two of them of male and one of them of female big toes, were published in full page, so the digits themselves, shockingly, are several times life-size. Disembodied, and dramatically lit against an ominous black background, these big toes are pungent in their detail: every stray hair, every striation of the skin, every bit of cracked nail varnish, is visible. As Michael Sheringham points out, "the close-up, aided by spotlighting blots out everything else, framing the big toe so that it emerges from a primal darkness." ${ }^{x x x i}$ Bataille's essay begins from the paradox I have been exploring in this article, namely that, though it is generally ignored and demeaned, associated with mud and darkness, "the big toe is the most human part of the human body, in the sense that no other element of this body is so differentiated from the corresponding element of the anthropoid ape". The big toe mocks or melodramatizes the constant, raging oscillation between ordure and the ideal, the ideal and ordure, which is characteristic of the confusion and frustration of human life. The upright gait of which humanity is so 
proud, according to Bataille, is founded on the foot, "but whatever the role the foot plays in his erection, man, who has a light head, a head raised to the heavens and heavenly things, regards it as spit, on the pretext that he has this foot in the mud." More than contempt, though, feet inspire a "secret terror" in humans, according to Bataille, and it is this that explains their "tendency to conceal, as far as possible, its length and form". The big toe, "hideously cadeverous and at the same time loud and defiant," as Boiffard's photographs also insist, is the index both of our animality and our humanity. ${ }^{\text {xxxii }}$

Building on Bataille, I want to end by pressing in a more polemical register for a philosophical reorientation of the human body. In order to understand the human being as a species that walks, which is shaped in its species being by walking, it is necessary radically to alter our perspective - as Gadda does before Michelangelo's and Raphael's paintings. We need to prostrate ourselves in the mud in order to gaze unflinchingly at this strange creature's big toe, its crucial point of connection with matter itself. Everything begins with the big toe, including being itself. It is by taking the big toe as its starting point, and as the point of contact with the world as brute matter, that we can best reorganize the semiotics of the body according to a materialist as opposed to an idealist paradigm. Marx famously announced that, inverting Hegel, he had set the dialectic back on its feet; I propose pivoting it on its big toe. Again, adapting a Hegelian formulation, it might be claimed that the being of Spirit is a toe bone.

The big toes in Boiffard's photographs stare at us - at once like "an alien organism", as Adam Lowenstein has suggested, and like something all too human. ${ }^{\text {xxxiii }}$ We must stare back at them unflinchingly, affirming our fear, horror and hilarity in order to celebrate their humanity and inhumanity alike. And in order to celebrate our 
humanity and inhumanity alike. In a fragment of his unpublished preface to Le Mort, Bataille described his experience as a tubercular patient in the autumn of 1942, when he happened upon the dead bodies of some German pilots shot down by an English fighter plane. "The foot of one of the Germans was bared [dénudée]," he records, "the sole of his shoe having been torn away." In contrast to the heads of the dead, which had been torched into indistinctness, "this foot alone was intact". He stared at this “diabolical”, "indecent”, "unreal” entity. He "remained motionless for a long time”, he recalls, "for this naked foot was looking at me." And this foot, he concludes, "had the violence - the negative violence - of truth. ${ }^{\text {"xxxiv }}$ A comparable image, with its challenge to our humanity, emerges in the essay on the big toe, in both Bataille's prose and Boiffard's photographs.

To scrutinize the big toe is to confront both our origins as an animal species and the dialectic of base and noble impulses that will determine our future. "A return to reality," Bataille writes in a final poetic formulation, "implies no new acceptance, but indicates that one is seduced basely, without transpositions and to the point of screaming, eyes wide open: open at the prospect of a big toe." ${ }^{\prime x x v}$

\footnotetext{
' Georges Bataille, 'Mouth,' in Visions of Excess: Selected Writings, 1927-1939, trans. Allan Stoekl (Minneapolis, 1985), 59.

ii Roland Barthes, 'The Outcomes of the Text,' in The Rustle of Language, trans. Richard Howard (Berkeley, 1989), 240-41.

iii See Bataille, 'The Jesuve,' in Visions of Excess, 78. The ape is the ultimate antibourgeois.

iv Bataille, 'Big Toe,' in Encyclopaedia Acephalica, Comprising the Critical Dictionary and Related Texts, trans. Iain White (London, 1995), 87, 90, 92.
} 
${ }^{\mathrm{v}}$ William Shakespeare, Coriolanus, in The Alexander Text of the Complete Works, ed. Peter Alexander (London, 1951), 829.

${ }^{\text {vi } B a t a i l l e, ~ ' B i g ~ T o e, ' ~} 92$.

${ }^{\text {vii }}$ Bataille, 'The Solar Anus,' in Visions of Excess, 8.

viii Bataille, '[Dream],' in Visions of Excess, 4.

${ }^{\text {ix }}$ Sigmund Freud, Three Essays on the Theory of Sexuality, in On Sexuality: Three Essays on the Theory of Sexuality and Other Works, trans. James Strachey, ed. Angela Richards (London, 1977), 96.

${ }^{x}$ Barthes, 'The Outcomes of the Text,' 245.

${ }^{\text {xi }}$ Bataille, 'Eye,' in Visions of Excess, 17.

xii Barthes, 'The Outcomes of the Text,' 245.

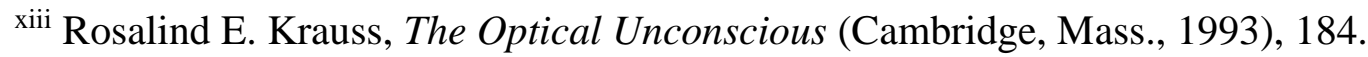

Patrick Ffrench confirms that 'Bataille's fiction of the body [...] is posed alongside the psychoanalytic semiotics of fetishism, not against it' - see 'Documents in the 1970s: Bataille, Barthes and 'Le gros orteil”,' Papers of Surrealism 7 (2007), 8. ${ }^{\text {xiv }}$ Charles Darwin, The Descent of Man: Selection in Relation to Sex, ed. Adrian Desmond and James Moore (London, 2004), 28.

${ }^{\mathrm{xv}}$ Quoted in Rebecca Solnit, Wanderlust: A History of Walking (London, 2001), 41.

${ }^{\text {xvi }}$ Leslie Klenerman and Bernard Wood, The Human Foot: A Companion to Clinical Studies (London, 2006), 9.

${ }^{\text {xvii }}$ Solnit, Wanderlust, 35 .

${ }^{\text {xviii }}$ For the range of hypotheses, see Solnit, Wanderlust, 40.

${ }^{\text {xix }}$ Campbell Rolian, Daniel E. Lieberman, and Benedikt Hallgrimsson, 'The Coevolution of Human Hands and Feet,' Evolution 64: 6 (2010), 1565-6. 
${ }^{\mathrm{xx}}$ Sigmund Freud, Civilization and its Discontents, trans. David McLintock (London, 2002), 41-2.

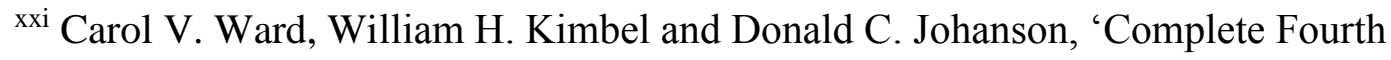
Metatarsal and Arches in the Foot of Australopithecus afarensis,' Science 331 (11 February 2011), 753.

xxii Joseph A. Amato, On Foot: A History of Walking (New York, 2004), p22.

xxiii Bataille, 'Big Toe,' 87.

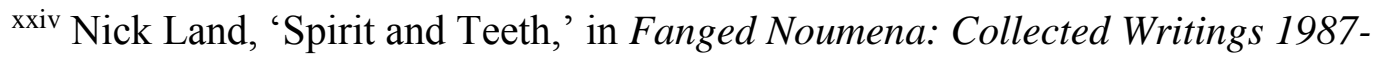

2007, ed. Robin Mackay and Ray Brassier (New York, 2011), 188.

${ }^{x x v}$ Carlo Emilio Gadda, That Awful Mess on the Via Merulana, trans. William Weaver (New York, 2007), 271-2. Hereafter, page references appear in parenthesis after the quotation.

${ }^{x x v i}$ Raymond Tallis, Michelangelo's Finger: An Exploration of Everyday

Transcendence (London, 2010), xvii.

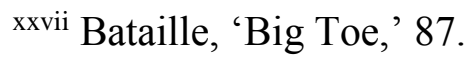

xxviii Thomas Pynchon, The Crying of Lot 49 (London, 2000), 46.

${ }^{\text {xxix }}$ Italo Calvino, 'Carlo Emilio Gadda, the Pasticcisccio,' in Why Read the Classics?

trans. Martin McLaughlin (London, 2009), 201.

${ }^{\mathrm{xxx}}$ Michel Surya, Georges Bataille: An Intellectual Biography, trans. Krzysztof Fijalkowski and Michael Richardson (London, 2002), 122-3.

${ }^{x x x i}$ Michael Sheringham, Everyday Life: Theories and Practices from Surrealism to the Present (Oxford, 2006), 96.

xxxii Bataille, 'Big Toe,' 92.

xxxiii Adam Lowenstein, 'The Surrealism of the Photographic Image: Bazin, Barthes, and the Digital Sweet Hereafter,' Cinema Journal 46: 3 (Spring 2007), 66. 
${ }^{\text {xxiv }}$ A translation of the fragment, from which these quotations are taken, appears in Lucette Finas, 'Reading Bataille: The Invention of the Foot,' diacritics 26: 2

(Summer 1996), 97-8.

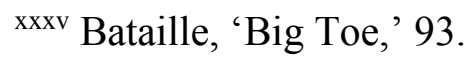

